\title{
Promoting patient comprehension of relevant health information
}

\author{
Gary L. Kreps(D)
}

\begin{abstract}
Patient understanding of health care recommendations provided by health care professionals is essential to enabling active and informed patient participation in care. Unfortunately, evidence suggests that patients often seriously misunderstand relevant health information provided to them, leading to errant patient decisions about their care. This commentary examines key communication factors that influence patient understanding and argues for a comprehensive approach to assessing and promoting patient comprehension.
\end{abstract}

Keywords: Health communication, Health literacy, Patient comprehension, Teach back method

\section{Commentary}

Promoting patient comprehension of health care recommendations is essential to the effective delivery of health care. Yet, patients often misunderstand relevant health information provided to them by health care practitioners, leading to dangerous errors in following recommended care plans [1-3]. Promoting patient understanding of diagnostic and prognostic information is a complex task due to numerous potential barriers to achieving high levels of understanding, including limitations in both the levels of patient health literacy and in health care providers' abilities to communicate complex health information clearly [4-6].

Health literacy is not just a trait that is rooted in patients' levels of education, intelligence, and communication competence, but is also a state that is influenced by the physical, cognitive, and emotional situations individuals experience [4]. The stresses of confronting being ill can have a very negative influence on levels of health literacy, making it difficult for health care providers to explain complex health issues to patients. Moreover, the process of explaining complex health issues is challenging for many health care providers, who need to communicate with culturally, relationally, and situationally sensitive language and examples that patients can understand and actively seek feedback from patients to assess their levels of understanding $[5,6]$. It is important for health researchers to carefully examine the processes of promoting patient

Correspondence: gkreps@gmu.edu

Center for Health and Risk Communication, George Mason University, 4400 University Drive, MS 3D6, Fairfax, Virginia 22030, USA comprehension of health information to increase understanding about the intricacies of consumer-provider health communication and to improve effective dissemination of relevant health information.

I commend Shiber, Zuker-Herman, Drescher, and Glezerman (2018) for embarking on their important research evaluating patient understanding of care plans communicated to patients while being seen in a hospital Emergency Department [7]. Emergency Department visits are especially challenging sites for effective consumer-provider communication due to the immediate time and attentional demands placed on health care providers who address health emergencies, as well as the fragile physical, mental, and emotional conditions of many patients receiving emergency care $[5,8]$. Promoting understanding of care plans is an essential part of Emergency Department care that enables patients to make informed decisions about their care and to follow care plan recommendations.

While the Shiber, Zuker-Herman, Drescher, and Glezerman (2018) study is a good start for examining this important issue, it does not appear to go far enough to fully assess patients' levels of comprehension of their care plans [7]. The researchers asked patients how well they understood the care plans described to them, without checking the accuracy of patients' comprehension of the health information provided. It is common for patients to report understanding relevant health information provided during health care visits, while actually being very poorly informed about their diagnoses, prognoses, and care plans $[3,5,6]$. Patients may 
think that they understand the health information provided to them, when not really fully comprehending relevant information. Patients are also likely to claim falsely to understand health care recommendations as an attempt to maintain face, appear to be competent, and to show that they are in-charge of their care [5, 6]. Patients may be embarrassed to report that they are confused and do not understand relevant health information. This can lead both health care providers and researchers to over-estimate levels of patient understanding of the health information provided to them.

National studies about medication adherence and international studies of health information dissemination have found that patients are often terribly misinformed about their health conditions, despite often believing that they are well informed [3,9-12]. These studies not only asked patients how much health information about their conditions that they understood, but also objectively tested the accuracy of their understanding about health conditions and treatment plans. Even when patients reported understanding their health conditions and treatment plans, these studies found that many of these patients were badly misinformed, did not report accurate understanding of their diagnoses, did not understand their treatment plans, and due to these information deficiencies did not faithfully follow their health care plan recommendations, often undermining the quality of their health care. For example, one national study in the US found that more than $50 \%$ of patients with serious chronic diseases were not taking the prescribed medications, often because they misunderstood information about their diagnoses, treatment plans, and the importance of their taking their medications [3]. Failure for many of these chronic disease patients to take their prescribed medications could be life-threatening.

Future research should expand upon the Shiber, Zuker-Herman, Drescher, and Glezerman study by implementing additional measures to fully assess patient understanding of their treatment plans [7]. I suggest employing objective tests of levels of patient understanding by asking patients to fully explain their diagnoses and treatment plans to the best of their abilities. Researchers can then compare these respondent explanations to the patients' actual diagnoses and treatment plans. This is a research application of the teach-back communication method, where providers ask their patients to explain the health information provided to them; research about the use of the teach back method found that this communication strategy can improve patient comprehension of health information provided to them in emergency care [13]. Researchers can also utilize other methods to assess understanding, including employing self-report measures, observational research strategies, and archival analysis of health records to increase confidence in research findings about patient comprehension $[14,15]$.

\section{Conclusions}

It is important to recognize the complexities of effective communication between health care providers and their patients, and to make certain that studies of patient comprehension of relevant health information are valid. The Shiber, Zuker-Herman, Drescher, and Glezerman study provides a good starting point for programmatic research about patient comprehension of relevant health information by examining the levels of patient confidence in understanding their care plans [7]. The next step in this program of research is to examine patients' actual levels of understanding. It will be interesting to compare patient estimates of comprehension about their care plans with their actual understanding about these care plans. This program of expanded patient comprehension research has great potential to guide development of important health communication programs, policies, and tools that can enhance quality of care and improve health outcomes.

\section{Authors' contributions}

The author read and approved the final manuscript.

\section{Authors' information \\ Gary L. Kreps is a University Distinguished Professor and Director of the Center for Health and Risk Communication at George Mason University. He formerly served as the founding Chief of the Health Communication and Informatics Research Branch at the National Cancer Institute, founding Dean of the School of Communication at Hofstra University, and Executive Director of the Greenspun School of Communication at UNLV.}

\section{Ethics approval and consent to participate}

(not applicable)

Consent for publication

(not applicable)

\section{Competing interests}

The author declares that he/she has no competing interests.

\section{Publisher's Note}

Springer Nature remains neutral with regard to jurisdictional claims in published maps and institutional affiliations.

Received: 21 August 2018 Accepted: 28 August 2018

Published online: 18 September 2018

References

1. Kindig DA, Panzer AM, Nielsen-Bohlman L. Health literacy: a prescription to end confusion. In: National Academies Press; 2004

2. National Academies of Sciences, Engineering, and Medicine. Building the case for health literacy: Proceedings of a Workshop. National Academies Press, 2018.

3. Kreps GL, Villagran MM, Zhao X, McHorney C, Ledford C, Weathers M, Keefe BP. Development and validation of motivational messages to improve prescription medication adherence for patients with chronic health problems. Pt Ed \& Counseling. 2011;83:365-71.

4. Amann J, Rubinelli S, Kreps GL. Revisiting the concept of health literacy: the patient as information seeker and provider. European Hlth Psych. 2015;17(6):286-90.

5. Kreps GL. One size does not fit all. Adapting communication to the needs and literacy levels of individuals. Annals Fam Med. 2016; http://www.annfammed.org/cgi/eletters/4/3/205

6. Ledford CJW, Villagran MM, Kreps GL, Zhao X, McHorney C, Weathers M, Keefe B. "Practicing medicine": patient perceptions of physician communication and the process of prescription. Pt Ed \& Counseling. 2010;80:384-92. 
7. Shiber S, Zuker-Herman R, Drescher MJ, Glezerman M. Gender differences in the comprehension of care plans in an emergency department setting. Israel J Hlth Policy Res. 2018;7:50. https://doi.org/10.1186/s13584-018-0245-9

8. Hess EP, Grudzen CR, Thomson R, Raja AS, Carpenter CR. Shared decisionmaking in the emergency department: respecting patient autonomy when seconds count. Acad Emergency Med. 2015;22(7):856-64

9. Kreps GL, Yu G, Zhao X, Chou SW, Hesse B. Expanding the NCl health information National Trends Survey from the United States to China and beyond: examining the influences of consumer health information needs and practices on local and global health. Journalism \& Mass Com Quarterly. 2017:94(2):515-25.

10. Zhao X, Mao Q, Kreps GL, Yu G, Li Y, Xu Z, Song M, Chou W-Y, Persoskie A, He R, Kim P. Cancer information seekers in China: a preliminary profile. J Hlth Com. 2015;20(5):616-26.

11. Oh KM, Jun J, Zhao X, Kreps GL. Cancer information seeking behaviors of Korean American women: a mixed methods study using surveys and focus group interviews. J Hlth Com. 2015;20(10):1143-54.

12. Hesse BW, Moser RP, Rutten $L$, Kreps GL. The Health Information National Trends Survey: Research from the baseline. J HIth Com. 2016;1 1(1):vii-xvi.

13. Griffey RT, Shin N, Jones S, Aginam N, Gross M, Kinsella Y, Williams JA, Carpenter CR, Goodman M, Kaphingst KA. The impact of teach-back on comprehension of discharge instructions and satisfaction among emergency patients with limited health literacy: a randomized, controlled study. J Com in Healthcare. 2015;8(1):10-21.

14. Alpert JM, Krist AH, Aycock BA, Kreps GL. Applying multiple methods to comprehensively evaluate a patient portal's effectiveness to convey information to patients. J Med Internet Res. 2016;18(5):e112. https://doi.org/10.2196/jmir.5451.

15. Kreps GL. Methodological diversity and integration in health communication inquiry. Pt Ed \& Counseling. 2011;82:285-91.

Ready to submit your research? Choose BMC and benefit from:

- fast, convenient online submission

- thorough peer review by experienced researchers in your field

- rapid publication on acceptance

- support for research data, including large and complex data types

- gold Open Access which fosters wider collaboration and increased citations

- maximum visibility for your research: over $100 \mathrm{M}$ website views per year

At BMC, research is always in progress.

Learn more biomedcentral.com/submissions 